Sai Yendamuri, MD, Roswell Park Cancer Institute "A MicroRNA Profile to Predict Recurrence After Surgical Resection of Stage I Non-Small Cell Lung Cancer"

CAREER DEVELOPMENT AWARD Salary support of up to $\$ 50,000$ a year for up to 2 years for applicants who have completed their residency training and who wish to pursue investigative careers in cardiothoracic surgery.

Arnar Geirsson, MD, Yale University

"Role of Micro RNA in Cardiac Ischemia and Heart Failure"

In 2009, TSFRE expanded its educational initiatives by offering two new education awards:

TSFRE/Edwards Lifesciences New and Emerging Technology Fellowship-Providing support of up to $\$ 30,000$ for a fellow to allow for travel, temporary relocation, and training costs associated with participating in a new or emerging technology training program.

Simulation Grants-To support the demonstration of the application of simulation in thoracic surgery education.

\section{Education Awards}

TSFRE is pleased to announce the following 2009 Education Awards:

TSFRE/Edwards Lifesciences New and Emerging Technology Fellowship:

Robert Smith, MD, Leipzig Heart Center

"Minimally Invasive/Percutaneous Valve"

Andrea Colli, MD, Leipzig Heart Center

"Endovascular Stents"
Cosmin Dobrescu, MD, Arizona Heart Center

"Endovascular Stents"

\section{Simulation Grants:}

Emile Bacha, MD, Children's Hospital of Boston

"Improving Performance of Emergent ECMO Cannulation in Pediatric Cardiac

Surgery Using High-Fidelity Simulation",

James I. Fann, MD, Stanford University Medical Center "Simulation in Cardiac Valve Surgery and Cardiac Surgery Crisis Management"

Yvonne Carter, MD, Georgetown University Medical Center

"Development of a Minimally Invasive Simulator for Thoracic Surgery Training"

Eugene A. Grossi, MD, New York University School of Medicine

"Cognitive Task Training for Right Upper Lobe Resection Simulator"

Richard H. Feins, MD, University of North Carolina School of Medicine

"Thoracic Resection Simulation",

Nabil Rizk, MD, Memorial Sloan Kettering Cancer Center

"Thoracic Endoscopic Surgery Simulator"

Ashish Shah, MD, Johns Hopkins Hospital

"Simulation Training for Post Operative Cardiac Instability and Collapse"

To learn more about the Thoracic Surgery Foundation for Research and Education or to make a donation to help support future research and education awards, please visit the TSFRE Web site at www.tsfre.org.

\section{The American Board of Thoracic Surgery}

\section{Notices}

The part I (written) examination was held on December 3. It is planned that this examination will be given at multiple sites throughout the United States using an electronic format. The closing date for registration is August 1 each year. Those wishing to be considered for examination must apply online at www.abts.org.

To be admissible for the Part II (oral) examination, a candidate must have successfully completed the Part I (written) examination.
A candidate applying for admission to the certifying examination must fulfill all the requirements of the Board in force at the time the application is received. Please address all communications to the American Board of Thoracic Surgery, 633 North St Clair Street, Suite 2320, Chicago, IL 60611 (telephone: 312-202-5900).

\section{Requirements for Maintenance of Certification}

Diplomates of the American Board of Thoracic Surgery (ABTS) who plan to participate in the Maintenance of Certification (MOC) process must hold an unrestricted medical license in the locale of their practice and privileges in a hospital 
accredited by the JCAHO (or other organization recognized by the ABTS). In addition, a valid ABTS certificate is an absolute requirement for entrance into the Maintenance of Certification process. If your certificate has expired, the only pathway for renewal of a certificate is to take and pass the Part I (written) and the Part II (oral) certifying examinations.

The names of individuals who have not maintained their certificate will no longer be published in the American Board of Medical Specialties Directories. Diplomates' names will be published upon successful completion of the Maintenance of Certification process.

The CME requirements are 30 Category I credits earned during each year prior to application. At least half of these CME hours need to be in the broad area of thoracic surgery. Category II credits are not allowed. Interested individuals should refer to the Booklet of Information for Maintenance of Certification for a complete description of acceptable CME credits. Diplomates will be expected to submit verification of CME earned.

Diplomates in the Maintenance of Certification process will need to provide a summary of their major cases performed during the year prior to application. The practice review should not exceed 100 cases.

Diplomates in the Maintenance of Certification process will be required to complete all sections of the SESATS self-assessment examination. It is not necessary for Diplomates to purchase SESATS individually, because it will be sent to them after their application has been approved.

Diplomates may apply for Maintenance of Certification in the year their certificate expires, or if they wish to do so, they may apply up to two years before it expires. However, the new certificate will be dated 10 years from the date of expiration of their original certificate or most recent recertification certificate. In other words, going through the Maintenance of Certification process early does not alter the 10-year validation. Diplomates certified prior to 1976 (the year that time-limited certificates were initiated) are also required to participate in MOC if they wish to maintain valid certificates.

The deadline for submission of application for the Maintenance of Certification is May 10 of each year. All ABTS diplomates will receive a letter from the Board outlining their individual timeline and MOC requirements. A brochure outlining the rules and requirements for Maintenance of Certification in thoracic surgery is available upon request from the American Board of Thoracic Surgery, 633 North St. Clair Street, Suite 2320, Chicago, IL 60611; telephone (312) 202-5900; fax (312) 202-5960; email info@abts.org. This booklet is also published on the website: www.abts.org. 